\title{
CORRESPONDENCE
}

\section{EMBL's databank}

SIR - We have had several comments concerning the recent letter from A. Slocum (Nature 7 October, p.482) describing a commercial timesharing service offered by Intelligenetics, Inc.

Intelligenetics makes available extensive software and computing capacity together with two nucleic acid sequence databases, including the one maintained by our group at the European Molecular Biology Laboratory (EMBL).

We wish to point out that the EMBL sequence data library has been sent to more than one thousand organizations, both academic and commercial. The data collection is supplied to everyone on the same basis: no restriction is made on its use or redistribution. Intelligenetics is free to offer access to the data in the context of their computing system, as is anyone else who may wish to do so. No-one has special or exclusive licence to the data: they remain freely available to any individual or organization directly from us.

\section{GREg HAMM}

Kurt Stueber

Graham Cameron

EMBL Nucleotide Sequence Data Library, Heidelberg, FRG

\section{Keep the index}

SIR - Having read King's critical comments (Nature 30 September, p.390), I would like to express my approval of your biotechnology stock index.

The success of these corporations will reflect the ability of biotechnology to find a place in public and private business. There are many more biotechnology corporations, some without public stock offerings, that are just as important. It is not necessary to list every firm to achieve a general overview, as Nature has done so well.

I hope Nature will not hesitate to add or drop corporations from the index in keeping with trends in this field.

SQuizzle Plekavich

Arlington, Massachusetts, USA

\section{Preventing wars}

SIR - I was pleased to read that J.R. Skoyles (Nature 7 October, p.482) approves of the proposals for a "comprehensive ban on all methods and means of warfare specifically designed to kill or injure by inducing human disease".

I feel that the criticisms with which he continues his letter are based on a misunderstanding of the second part of my letter (Nature 9 September, p.102). It was concerned only with the disarmament side of the disarmament/international security relationship ${ }^{1}$, as is the UN draft Comprehensive Programme of Disarmament (CPD). The draft was referred by the UN Second Special Session on Disarmament back to the Geneva Committee on Disarmament for them to bring a revised version to the 1983 regular Session of the General Assembly. We believe that the content of the draft should be a matter for informed public discussion and comment, and wish to contribute to encouraging this.

The approach in the existing draft CPD is across-the-board disarmament in three (or four) stages. The arguments against this approach are: a 50 -year history of political failure; the unrealistic requirement diplomatically and technically for simultaneous negotiations and verifications in all five categories of disarmament measures of Stage I; requiring the final stage of nuclear disarmament to coincide with the final stage of conventional disarmament, despite uncertainty on whether world society can achieve the latter; and the preclusion of a selective comprehensive treaty banning non-nuclear weapons of mass destruction and all diseaseinducing methods of warfare, which is the only immediately feasible treaty of comprehensive disarmament ${ }^{2}$.

The specific measures mentioned in the second part of my letter were only suggestions of what hopefully might follow the conclusion of such a treaty, if the disarmament diplomats could be persuaded to replace their "disarmament in layers" by a more meaningful approach.

JEFFREY SEGALL

\section{London NW2, UK}

1. UN. A/36/597, 19 November 1981

2. Meeting of Professions for World Disarmament and Development, 2 Oct. 1982.

\section{The fetal soul}

SIR -1 beg leave to disagree with the comment in your leading article that "gastrulation is the latest point at which twinning can occur and thus the first point at which one body can have a unique soul" (Nature 7 October, p.475).

In one of the most solemn declarations of the Catholic Church Pope Pius IX in 1854 declared:

The blessed Virgin Mary was, in the first instant of her conception, through the merits of Jesus Christ the saviour of the human race, by a singular grace and privilege of God almighty, preserved immune from every stain of original sin.

It is thus certain for Catholics that the soul enters the fetus at conception. If the physical fetus divides, God is as capable of creating a second soul as He was of creating the first thus both bodies will have immortal souls, each of which will eventually spend eternity in a state of friendship with God (Heaven) or enmity with God (Hell).

Dave Parry

Glasgow G12, UK

\section{Costly journals}

SIR - Robert Campbell was right to point out in an introduction to New Journals Review (Nature 7 October, p.49) that falling circulations do bring sharp increases in journal prices, thus causing a further drop in subscription levels, and further price increases.
It is a problem we have been interested in for some time now ${ }^{\prime}$ and have studied quantitatively in relation to physics periodicals. The problem facing libraries is indeed difficult. Taking our sample of 160 journals as an example, if a library wanted to keep up with both the growth in the number of core physics journals and their rising prices, it would have needed to increase its subscription budget by a factor of 30 since 1957 .

We have shown elsewhere ${ }^{3}$ that most of the price increases can be attributed to falls in circulations, but we have also demonstrated that, for the last few years, journal prices have been rising in anticipation of even greater circulation falls (see figure).

The timing of this change corresponds to a fall in the size of the market for physics journals. Unless some drastic steps are taken to reverse this trend, we predict that, as far as physics journals are concerned, the circulation

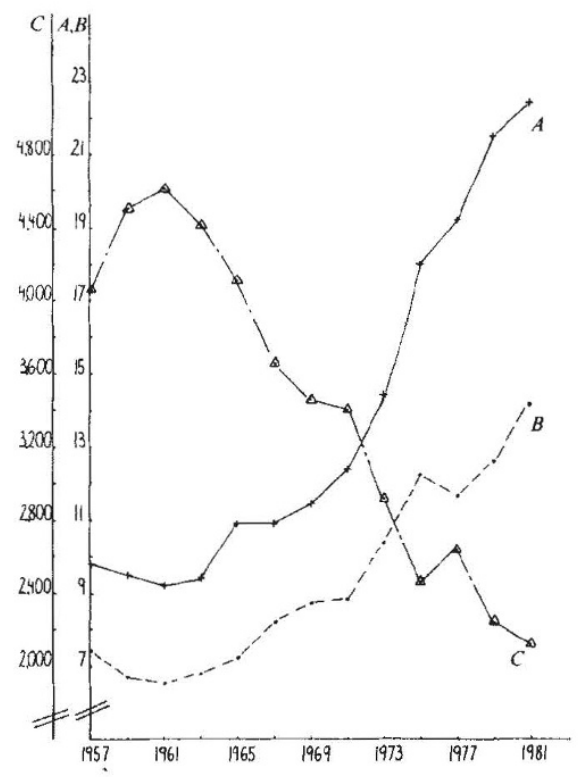

Graph showing the impact of the fall in circulation on journal prices in a sample of 160 core physics journals. Scale $A$, the actual price per standard volume, in constant (1957) dollars; $B$, the "expected" price per standard volume, in constant (1957) dollars; $C$, the average circulation per title for journals in the sample. A standard volume contains 500 standard pages ${ }^{1}$. The "expected" price is calculated by taking into account increases in publishing costs and falls in circulation ${ }^{2}$. Note the incrcasing divergence of the two pricc curves.

will continue to fall ${ }^{3}$. By the year 2000 , the average subscription level of a core physics journal will be approximately 900 , a fivefold drop since the late 1950s. Prices will, of course, continue to rise.

\section{S. CHOMET}

E. Pollitzer

Department of Physics,

Kings College,

London WC2, UK

1. Chomet, S. \& Nejman, E. Nature 279, 188 (1979).

2. Nejman E. thesis, Univ. London (1981).

3. Chomet S. \& Nejman E. J Research Commun. Stud. $3,185(1981)$ 